\title{
Familial hypothyroidism with autosomal dominant inheritance
}

\author{
M Mimouni, A Mimouni-Bloch, J Schachter, M Shohat
}

\begin{abstract}
Three generations of a family with clinical and subclinical hypothyroidism caused by thyroid stimulating hormone (TSH) unresponsiveness are described. Findings were low to normal serum thyroxine, raised serum TSH, and low radioiodine uptake; goitre was notably absent. This family is the first evidence of an autosomal dominant mode of transmission of TSH unresponsiveness and may enable identification of the precise defect by genetic linkage study.

(Arch Dis Child 1996;75:245-246)
\end{abstract}

Keywords: non-goitrous hypothyroidism, thyroid stimulating hormone unresponsiveness.

Hypothyroidism is caused by various pathophysiological mechanisms. ${ }^{1}$ Among these, thyroid stimulating hormone (TSH) unresponsiveness is rare and has been reported in only a few isolated patients, two of whom were the product of consanguineous matings. ${ }^{2-4}$ This condition has an autosomal recessive mode of inheritance. $^{56}$

We describe a family in which clinical or subclinical hypothyroidism caused by TSH unresponsiveness was observed in three generations, suggesting an autosomal dominant disorder. This family may represent the first evidence of an autosomal dominant TSH receptor defect.

Schneider Children's Medical Centre of Israel, Beilinson Medical Campus, Petah Tiqva, and Sackler Faculty of Medicine, Tel Aviv University, Tel Aviv, Israel, Paediatric Emergency and Day Care Department M Mimouni A Mimouni-Bloch J Schachter

Department of Medical Genetics M Shohat

Correspondence to: Dr M Mimouni, Paediatric Emergency and Day Care Department, Schneider Children's Medical Centre of Israel, Beilinson Medical Campus, Petah Tiqva 49202, Israel.

\section{Clinical description}

The pedigree of this family is presented in fig 1. The propositus (IV.7) was born in 1977 to unrelated parents of Jewish Ashkenazic origin. At the age of 3.8 years, he was referred to our clinic with high TSH and low thyroxine concentrations and a family history of hypothyroidism. He was at the 30 th centile for weight and height. On clinical examination there were no signs of either hypothyroidism or goitre. Free thyroxine was $8 \mathrm{pmol} / \mathrm{l}$ (normal 11-26 $\mathrm{pmol} / \mathrm{l}$ ) and TSH $100 \mathrm{mU} / 1$ (normal 1-4 $\mathrm{mU} / \mathrm{l}$ ). Bone age (according to the Greulich and Pyle atlas) was severely retarded, compatible with 1.3 years of age. Thyroid scan with $I^{131}$ showed low iodine uptake, $5 \%$ at two hours and $11 \%$ at 24 hours (normal $15 \%$ and $40 \%$ ), with the thyroid gland in the normal anatomic site.

Thyroxine treatment was started and TSH and serum thyroxine concentrations progressively became normal. The propositus is now 17 years old, well developed, with normal TSH and thyroxine concentrations on $150 \mathrm{mg} /$ day of thyroxine. Mental development is normal, and hearing tests revealed no abnormalities.

When the patient was first evaluated, we decided to examine the entire family in an attempt to define the mode of inheritance and the pathophysiology of the hypothyroidism. Laboratory tests were performed one month after treatment was stopped for those who were treated; results are summarised in table 1. Affected individuals were defined as those with raised $\mathrm{TSH}$ and normal or decreased free thyroxine.

All the affected individuals available for investigation (II.5, III.2, III.3, III.5, IV.1, IV.2, IV.4, IV.6, IV.7) were born after a normal pregnancy with normal birth weight and height. Psychomotor development was also normal, with no cases of mental retardation.

At the time of the patient's first evaluation, none of the children (IV.1, IV.2, IV.4, IV.6, IV.7) showed a classic picture of hypothyroidism, and none except IV.4 had goitre on clinical examination. All the children had normal growth, with weight and height centiles between 25 and 50 . Bone age of IV.1 and IV.2 was normal while that of IV.4, IV.6, and IV.7 showed a six to 30 month lag.

IV.4 had previously undergone a thyroid scan with $\mathrm{I}^{131}$ that showed low iodine uptake, $10.5 \%$ at two hours and $5.4 \%$ at 24 hours, with normal anatomy. Among the previous generations, III. 2 was a known hypothyroid patient who had been on replacement treatment since the age of 6 years. The other affected adults (II.5, III.3, III.5) had no signs of clinical hypothyroidism. II.7 and III.7 live in another country; they are known to have hypothyroidism and are being treated with thyroxine, but we have no detailed history on them. I.1 and I. 2 are deceased. II.1, II.2, II.3, II.4, II.8, III.8, and III.9 were not evaluated. They are not known to suffer from hypothyroidism.

To achieve a better understanding of the defect, we conducted further tests. The thyro-

Table 1 Results of thyroid investigations in treated subjects

\begin{tabular}{lccll}
\hline & $\begin{array}{l}\text { Free } \\
\text { thyroxine } \\
(\text { pmolll) }\end{array}$ & $\begin{array}{l}\text { TSH } \\
(\mathrm{mU} / \mathrm{l})+\end{array}$ & $\begin{array}{l}\text { Radioiodine } \\
\text { uptake }\end{array}$ & $\begin{array}{l}\text { TRH test } \\
\text { peak TSH } \\
(\mathrm{mU} / \mathrm{l})\end{array}$ \\
\hline II.5 & 13.6 & 5.5 & - & 64 \\
III.2 & 4.0 & $>100$ & - & - \\
III.3 & 10.2 & 10.6 & - & $>100$ \\
III.5 & 18.3 & 34.6 & - & $>100$ \\
IV.1 & 8.5 & 77.0 & Low & - \\
IV.2 & 6.5 & $>100$ & Low & - \\
IV.4 & 11.0 & $>100$ & Low & - \\
IV.6 & 15.0 & 17.8 & Low & - \\
IV.7 & 8.0 & 100 & Low & - \\
\end{tabular}

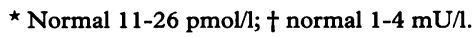




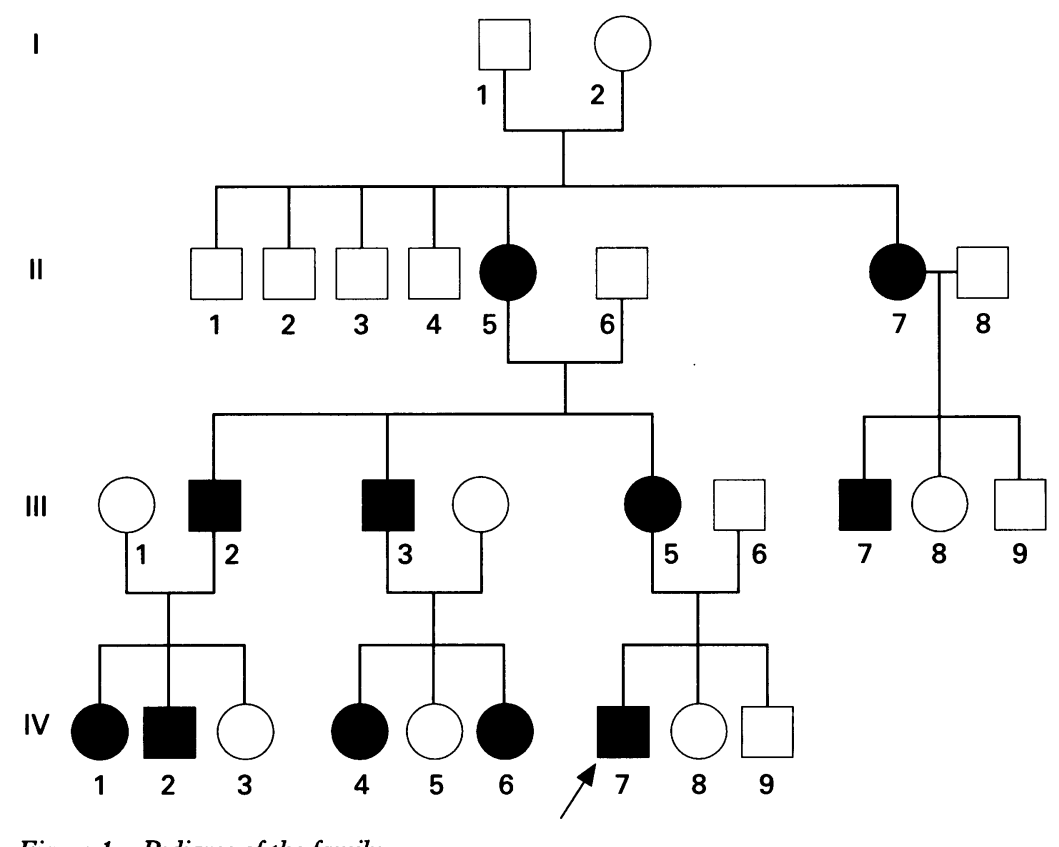

Figure 1 Pedigree of the family.

trophin releasing hormone (TRH) test, performed on II.5, III.3, and III.5, elicited a high TSH response. Thyroid scan with $\mathrm{I}^{131}$, performed on IV.1, IV.2, and IV.6, showed low uptake $(3.8 \%, 12 \%$, and $9 \%$ at 24 hours, respectively), with normal anatomic position of the gland. Thyroid antibodies and antinuclear antibodies were negative in all cases. HLA typing was not contributory.

A TSH bioassay of all the members of the family was carried out in FRTL-5 cells, a line of differentiated rat thyroid cells (generously provided by Dr Ambesi-Impombato, Naples, Italy). The assay was done according to the method of Bidey et al. ${ }^{7}$ Results showed that the TSH activity of this family was within normal limits. Further evaluation of the defect by administration of bovine TSH was not performed for ethical reasons. ${ }^{5}$ All the members of the family refused a thyroid biopsy.

\section{Discussion}

In the family presented, the disease was characterised by low to normal serum thyroxine, raised serum TSH, and low radioiodine uptake. Expression was variable, with no severely affected individuals. The most outstanding feature was the absence of goitre (apart from one case) despite the high serum TSH concentration, which made a diagnosis of a congenital defect in thyroid iodide transport or organification unlikely. ${ }^{18}$

The absence of goitre and of thyroid antibodies also ruled out an autoimmune disorder. Congenital non-goitrous hypothyroidism has been occasionally described as familial $^{8}$ with a possible autosomal recessive mode of inheritance. In the family presented, hypothyroidism was obviously transmitted as an autosomal dominant trait.

Based on the in vitro studies in FRTL-5 cells, we concluded that the TSH bioactivity was within the normal range, and as such, the defect must lie somewhere between the TSH receptor binding site and receptor cyclase binding protein. This was in agreement with the relatively mild phenotype observed in this family, as expected for a receptor defect.

Stanbury et al, ${ }^{2}$ Codaccioni $e t a l,{ }^{3}$ MedeirosNeto et $a l^{4}{ }^{4}$ and Sunthornthepvarakul et al described sporadic cases of TSH unresponsiveness, apparently inherited as an autosomal recessive trait.

Our family constitutes the first evidence of an autosomal dominant mode of transmission of TSH unresponsiveness. This family therefore demonstrates possible genetic heterogeneity for this specific type of hypothyroidism. With the recent progress in gene mapping of the TSH receptor (chromosome $14 \mathrm{q} 31$ ), ${ }^{10}$ this family may enable identification of the precise defect by genetic linkage study. We are currently in the process of DNA collection from an appropriate number of family members to examine the possibility of an abnormality in TSH receptor function.

1 Reed-Larsen P, Ingbar SH. The thyroid gland. In: Wilson JD, Foster DW, eds. Williams textbook of endocrinology. JD, Foster DW, eds. Williams textbook of

2 Stanbury JB, Rocmans P, Buhler UK, Ochi Y. Congenital Stanbury JB, Rocmans P, Buhler UK, Ochi Y. Congenital
hypothyroidism with impaired thyroid response to thyrotropin. $N$ Engl f Med 1968; 279: 1132-6.

3 Codaccioni $\mathrm{JL}$, Carayon $\mathrm{P}$, Michel-Bechet $\mathrm{M}$, et al. Congenital hypothyroidism associated with thyrotropin unresponsiveness and thyroid cell membrane alterations. $\mathcal{f}$ Clin Endocrinol Metab 1980; 50: 932-7.

4 Medeiros-Neto GA, Knobel M, Bronstein MD, et al. Impaired cyclic-AMP response to thyrotropin in congenita hypothyroidism with thyroglobulin deficiency. Acta Endo crinol 1979; 92: 62-79.

5 Dumont JE, Vassart G, Refetoff S. Thyroid disorders. In Scriver CR, Beaudet AL, Sly WS, Valle D, eds. The metabolic basis of inherited disease. 6th Ed. New York: McGraw Hill, 1989: 1843-80.

6 McKusick VA. Mendelian inheritance in man. Catalogs of autosomal dominant, autosomal recessive and $X$-linked phenotypes. 10th Ed. Baltimore: The Johns Hopkins University types. 10th Ed. Baltim

7 Bidey SP, Chiovato L, Day A, et al. Evaluation of the rat thyroid strain FRTL-5 as an in vitro bioassay system for thyro-

8 White CW, Wiedermann BL, Rebecca TK, et al. Hereditary congenital non-goiterous hypothyroidism. Am $\mathcal{F}$ Dis Child 1981; 135: 568-9.

9 Sunthornthepvarakul T, Gottschalk ME, Hayashi Y, et al. Brief report: resistance to thyrotropin caused by mutations in the thyrotropin receptor gene. N Engl f Med 1995; 332: 155-60.

10 Rousseau-Merck MF, Misrachi M, Lossfelt H, et al. Assignment of the human thyroid stimulating hormone receptor 233-6. 